\title{
Effect of Pseudomonas aeruginosa exotoxin A on endotoxin-induced tumour necrosis factor production in murine lung
}

\author{
YOICHI HIRAKATA, TERUO KIRIKAE $\dagger$, FUMIKO KIRIKAE $\dagger$, TOSHIYUKI YAMAGUCHI, KOHICHI \\ IZUMIKAWA, HIROMU TAKEMURA, SHIGEFUMI MAESAKI*, KAZUNORI TOMONO*, YASUAKI \\ YAMADA, SHIMERU KAMIHIRA, MASAYASU NAKANO $\dagger$, SATOSHI KITAMURA $\ddagger$ and SHIGERU \\ KOHNO*
}

Departments of Laboratory Medicine and * Second Department of Internal Medicine, Nagasaki University School of Medicine, 7-1 Sakamotomachi, Nagasaki 852-8501 and Departments of † Microbiology and $\ddagger$ Pulmonary Medicine, Jichi Medical School, Minamikawachi, Tochigi 329-0498, Japan

\begin{abstract}
The ability of several Pseudomonas aeruginosa exo-enzymes, including exotoxin A (ETA), to induce inflammation and their influence on endotoxin-induced tumour necrosis factor (TNF) production in murine lung were evaluated. Intratracheal administration of lipopolysaccharide (LPS; 0.1-10 $\mu \mathrm{g} /$ mouse), $2^{-1}$ LD50 of $P$. aeruginosa alkaline protease (7.5 $\mu \mathrm{g} /$ mouse) and elastase $(1.2 \mu \mathrm{g} / \mathrm{mouse})$ elevated total cell number and the percentage of neutrophils in broncho-alveolar lavage fluid (BALF), whereas ETA $(0.1 \mu \mathrm{g} / \mathrm{mouse})$ did not. LPS induced TNF production in BALF in a dose-dependent manner, whereas the $P$. aeruginosa exo-enzymes did not. When ETA was inoculated into the respiratory tract before LPS, production of TNF in BALF was significantly suppressed in a dose-dependent manner. ETA also suppressed TNF production by alveolar macrophages (AMs) stimulated with LPS in vitro. Flow cytometric analysis showed that ETA markedly reduced the expression of CD14 and CD11c/CD18 on the surface of AMs. ETA also depressed partially the expression of TNF- $\alpha$ mRNA in AMs. These findings suggest that ETA regulates TNF production in murine lung by suppressing LPS receptor expression, mRNA expression and protein synthesis and/or secretion of TNF.
\end{abstract}

\section{Introduction}

Pseudomonas aeruginosa is the most prevalent pathogen in patients with cystic fibrosis (CF) [1-3] and diffuse panbronchiolitis (DPB) $[4,5]$. Recently, high concentrations of tumour necrosis factor alpha (TNF- $\alpha$ ) in sputum and broncho-alveolar lavage fluid (BALF) from patients with CF [6-8] and DPB [9] were reported. TNF- $\alpha$, produced by alveolar macrophages (AMs) in response to $P$. aeruginosa and other organisms, may promote the destructive inflammatory process in the lung [7].

As $P$. aeruginosa is a gram-negative bacillus, endotoxin (lipopolysaccharide; LPS) of this pathogen should be an important virulence factor [10]. However, LPS from the cell wall of $P$. aeruginosa is not as toxic as that from enterobacteria [10]. P. aeruginosa also produces numerous extracellular products which are much more toxic than LPS and have been shown to play a role in the pathogenesis of the infections

Received 16 April 1998; accepted 1 Sept. 1998.

Corresponding author: Dr Y. Hirakata. caused by this organism [10-12]. In CF patients colonised or infected by $P$ aeruginosa, exo-enzymes such as exotoxin A (ETA), elastase (EL) and alkaline protease (AP) are detectable in the sputum and their concentrations are high during exacerbations [13, 14]. Furthermore, the high percentage of patients with serum antibodies specific for ETA [15] and proteases [16] suggests that these exo-enzymes contribute to the pathogenesis of the disease [13]. A role for ETA and EL in the virulence of $P$ aeruginosa in chronic lung infections of rats has been demonstrated [17]. A previous study [12] reported that intravenous administration of ETA, the most toxic substance produced by $P$. aeruginosa, enhanced LPS-induced TNF- $\alpha$ production in blood of mice, when ETA was injected before or at the same time as LPS. However, it is unclear whether ETA or other extracellular products of $P$. aeruginosa induce TNF production by themselves, or influence LPS-induced TNF production in lung. To elucidate these points, the present study evaluated the influence of intratracheal administration of $P$. aeruginosa ETA, EL and AP on inflammation and TNF production in BALF of mice. The influence 
of pre-treatment with ETA and other exo-enzymes on LPS-induced TNF production was also examined. In addition, the influence of ETA on expression of LPS receptors on the surface of murine AMs and also on TNF- $\alpha$ mRNA expression in the cells was examined.

\section{Materials and methods}

Animals

Specific-pathogen-free male ddY mice (Japan SLC, Shizuoka, Japan) weighing 24-28 g were used.

\section{Bacterial products}

P. aeruginosa exotoxin A (ETA; List Biological Laboratories, San Mateo, Ca, USA), $P$. aeruginosa elastase (EL; Nagase Biochemicals, Kyoto, Japan), $P$. aeruginosa alkaline protease (AP; Nagase) and LPS derived from Escherichia coli O55:B5 (Difco Laboratories) were purchased commercially. These bacterial products were dissolved in pyrogen-free saline just before use. LD50 doses of intratracheally inoculated ETA, EL and AP in mice were determined after observation for 14 days and calculated according to the method of Karber [18]. In in-vivo studies, mice were inoculated intratracheally with $2^{-1}$ LD50 of exoenzymes (ETA, $0.1 \mu \mathrm{g} /$ mouse; AP, $7.5 \mu \mathrm{g} /$ mouse; $\mathrm{EL}, 1.2 \mu \mathrm{g} / \mathrm{mouse})$ and LPS $0.1-10 \mu \mathrm{g} /$ mouse.

\section{Intratracheal cannulation and administration of bacterial products}

Mice were anaesthetised with ether. The trachea was cannulated through the mouth by means of an ear pick with a light (Mimi-pick) as a laryngoscope, without any surgical operation [19]. Bacterial products in $0.2 \mathrm{ml}$ of pyrogen-free saline were administered to mice intratracheally via a $20 \mathrm{G}$ intravenous cannula.

\section{Collection of BALF and serum samples}

BALF was obtained by washing murine lung with $1.0 \mathrm{ml}$ of saline three times. Total and differential cell counts were performed with Giemsa's stain. After centrifugation of the BALF, the supernates were frozen at $-80^{\circ} \mathrm{C}$ until TNF assay. In some experiments, blood was obtained by cardiac puncture and serum samples were also used for TNF assay.

\section{Influence of $P$. aeruginosa exo-enzymes on LPS- induced TNF production in murine lung}

Mice were given $P$. aeruginosa exo-enzymes at a dose of $2^{-1}$ of LD50 in $0.2 \mathrm{ml}$ of pyrogen-free saline or saline alone intratracheally via the cannula. Mice were given $0.001-1 \mu \mathrm{g}$ of LPS intratracheally $4 \mathrm{~h}$ after administration of $P$. aeruginosa exo-enzymes. BALF was obtained as described above for the TNF assay.

\section{Alveolar macrophage culture}

The cells in BALF obtained from normal mice were cultured in 96-well microtitration plates at a concentration of $1 \times 10^{5}$ cells/well in RPMI1640-fetal calf serum $5 \%$ overnight at $37^{\circ} \mathrm{C}$. Non-adherent cells were removed by three washes and the resultant adherent cells were used as alveolar macrophages (AMs). AMs were incubated with ETA $0.008-5 \mu \mathrm{g} / \mathrm{ml}$ for $4 \mathrm{~h}$ at $37^{\circ} \mathrm{C}$. Then LPS was added to a final concentration of $1000 \mathrm{ng} / \mathrm{ml}$. Incubation was continued for $2 \mathrm{~h}$ and the culture supernates were collected for TNF assay.

\section{TNF assay}

TNF activity was measured by a L929 cytotoxicity assay based on reduction of a tetrazolium dye [20]. Briefly, murine TNF-sensitive L929 cells were cultured in 96well microtitration plates at a concentration of $5 \times 10^{4} /$ well in RPMI1640-fetal calf serum $5 \%$ and incubated for $20 \mathrm{~h}$ at $37^{\circ} \mathrm{C}$. The cells were then cultured for a further $18 \mathrm{~h}$ in the presence of serial dilutions of the test samples with actinomycin D (Sigma) $2 \mu \mathrm{g} / \mathrm{ml}$ to increase sensitivity to TNF. The viability of cells was determined by a quantitative colorimetric staining assay with MTT (3-(4, 5-dimethylthiazol-2-yl)-2, 5-diphenyltetrazolium bromide; Sigma) $1 \mathrm{mg} / \mathrm{ml}$. The $\mathrm{OD}_{590}$ of the dissolved precipitate was determined in a spectrophotometer. TNF activity was expressed in units $/ \mathrm{ml}$, with $1 \mathrm{U}$ being the amount of TNF causing $50 \%$ lysis of L929 cells.

\section{Detection of TNF- $\alpha$ mRNA expression}

Mice were given ETA $0.1 \mu \mathrm{g} /$ mouse intratracheally followed by LPS $0.01 \mu \mathrm{g} 4 \mathrm{~h}$ later. BALF was obtained $90 \mathrm{~min}$ after LPS inoculation. Total cell RNA was isolated by lysing the cells in isogen (Nippon Gene, Toyama, Japan) [21] following the manufacturer's protocol. The influence of ETA on mRNA expression was examined by reverse transcription PCR (RT-PCR) [22]. RT-PCR was performed in $100-\mu 1$ reactions with a GeneAmp $^{\mathrm{TM}}$ RNA PCR kit (Roche, Branchburg, NJ, USA) with cloned moloney murine leukaemia virus (M-MLV) reverse transcriptase (final concentration $2.5 \mathrm{U} / \mu \mathrm{l}$ ) with the GeneAmp PCR System 9600-R (Roche). cDNA was analysed and amplified by PCR with primers specific to murine TNF- $\alpha$ and $\beta$-actin. Primers used were as follows: mouse TNF- $\alpha$ sense, $5^{\prime}$ TTC TGT CTA CTG AAC TTC GGG GTG ATC GGT CC-3'; mouse TNF- $\alpha$ anti-sense, 5'-GTA TGA GAT AGC AAA TCG GCT GAC GGT GTG GG-3' [23]; mouse $\beta$-actin sense, 5'-GTG GGC CGC TCT AGG CAC CA-3'; mouse $\beta$-actin anti-sense, $5^{\prime}$-CGG TTG GCC TTA GGG TTC AGG GGG-3' [24]. PCR was performed at $94^{\circ} \mathrm{C}$ for $2 \mathrm{~min}$, followed by 35 cycles of $30 \mathrm{~s}$ at $95^{\circ} \mathrm{C}, 30 \mathrm{~s}$ at $55^{\circ} \mathrm{C}$ and $30 \mathrm{~s}$ at $72^{\circ} \mathrm{C}$. PCR products were subjected to agarose $2 \%$ gel electrophoresis. DNA was then visualised after staining with ethidium bromide. Signals obtained for TNF- $\alpha$ (354 bp) and $\beta$-actin (245 bp) PCR products were 
analysed by densitometry with Dendron software (Soltech, Oakdale, CA, USA) and the ratio of densitometric values for TNF- $\alpha$ and $\beta$-actin signals was calculated to normalise the expression of TNF- $\alpha$ to $\beta$ actin.

Flow cytometric analysis of $C D 14$ and $C D 11 c / 18$ expression on the surface of AMs

Mice were given $0.1 \mu \mathrm{g}$ of ETA or saline intratracheally. BALF were obtained $4 \mathrm{~h}$ after ETA inoculation. Total cell numbers in BALF were adjusted to $1.0 \times$ $10^{6}$ cells $/ \mathrm{ml}$ and the cells were stained with rat fluorescein isothiocyanate (FITC)-conjugated anti-CD14 monoclonal antibody (MAb; clone rmC5-3) and hamster phycoerythrin (PE)-conjugated anti-CD11c/ CD18 MAb (clone HL3) for $30 \mathrm{~min}$ at room temperature. After washing, labelled cells were gated in an area of macrophages on the scatter cytogram and analysed by Cytron Flow Cytometry (Ortho Diagnostic System KK, Tokyo, Japan). The percentage of positive and mean intensities for the antigens were calculated by the manufacturer's programme. Control preparations were set up by replacing the MAbs with a mouse immunoglobulin of the same isotype.

a

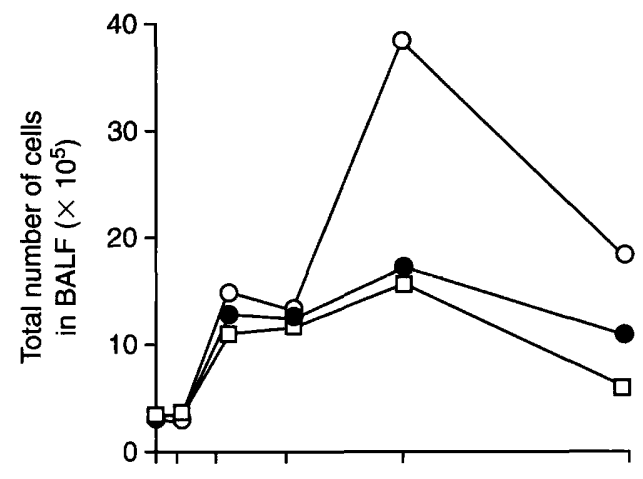

b

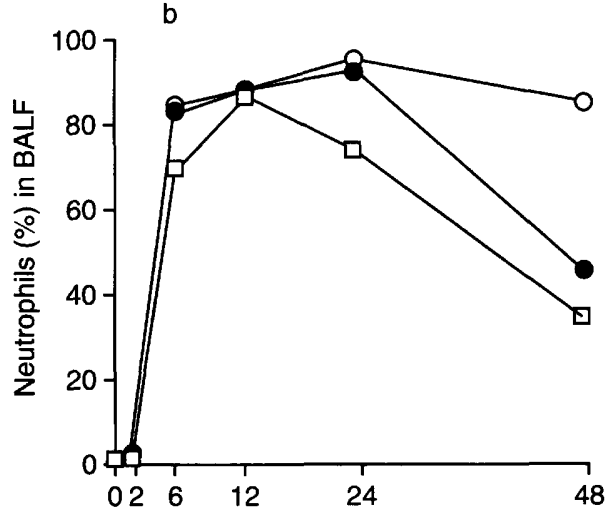

Statistical analysis

Student's $t$ test was used to compare means and a level of $5 \%$ was considered significant.

\section{Results}

Augmentation of total and differential cell counts in $B A L F$ after intratracheal administration of LPS, ETA, AP or EL

Total and differential cell counts in BALF taken from the mice given LPS $0.1-10 \mu \mathrm{g} /$ mouse intratracheally did not change until $2 \mathrm{~h}$ after inoculation and increased $6 \mathrm{~h}$ after inoculation (Fig. 1a and b). The peak of total cell numbers was observed $12-24 \mathrm{~h}$ after LPS inoculation. The percentage of neutrophils was quickly elevated when LPS was inoculated. None of the mice died of intratracheal inoculation at these doses of LPS. Intratracheal inoculation of $2^{-1}$ LD50 of ETA $(0.1 \mu \mathrm{g} /$ mouse $)$, AP $(7.5 \mu \mathrm{g} /$ mouse $)$ or EL $(1.2 \mu \mathrm{g} /$ mouse $)$ did not produce any obvious change in total or differential cell counts until $6 \mathrm{~h}$ after inoculation (Fig. 1c and d). Thereafter, total cell numbers in BALF of mice inoculated with AP or EL, but not ETA, increased significantly (Fig. 1c). Elevation
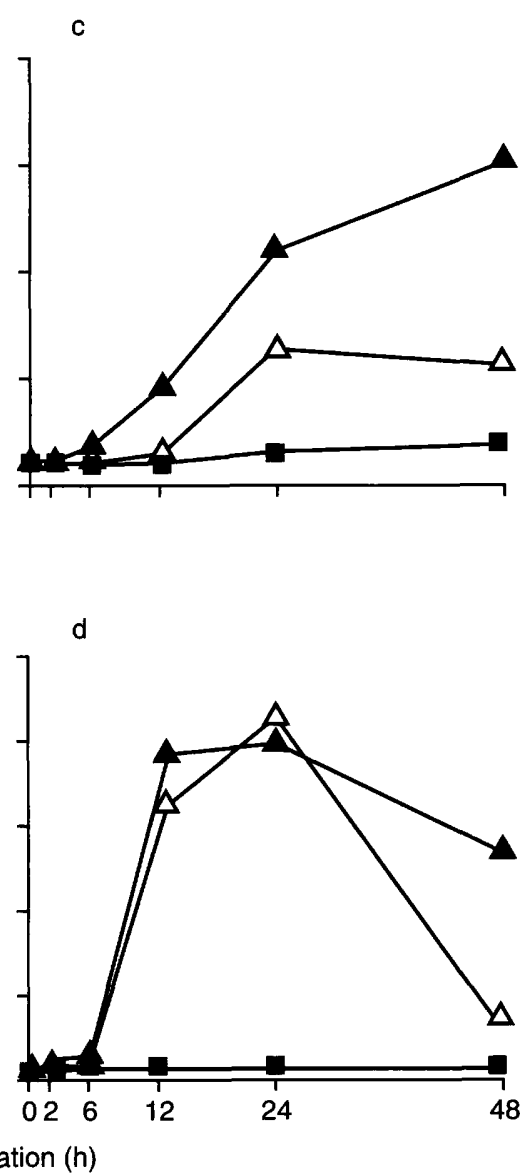

Fig. 1. Time changes of total cell counts and percentage of neutrophils in BALF of mice after intratracheal inoculation of various doses of LPS $(0,10 \mu \mathrm{g} ; \bullet, 1 \mu \mathrm{g} ; \square, 0.1 \mu \mathrm{g})$ and $2^{-1}$ LD50 of P. aeruginosa AP $(\Delta)$, EL $(\triangle)$ and ETA $(\square)$. After intratracheal inoculation with $0.1-10 \mu \mathrm{g}$ of $E$. coli $\mathrm{O} 55: \mathrm{B} 5 \mathrm{LPS}$ in $0.2 \mathrm{ml}$ of pyrogen - free saline, time changes of total cell counts (a) and percentage of neutrophils (b) in BALF were examined. P. aeruginosa AP, EL or ETA at doses of $2^{-1}$ LD50 were also inoculated and time changes of total cell counts (c) and percentage of neutrophils (d) in BALF were examined. The results are expressed as the mean of at least three mice per group. 
of the percentage of neutrophils was observed at $12 \mathrm{~h}$ and peaked at $24 \mathrm{~h}$ after inoculation in all groups of mice except for those given ETA (Fig. 1d).

\section{TNF levels in BALF after intratracheal administration of LPS, ETA, AP or EL}

Intratracheal administration of LPS $1 \mu \mathrm{g} /$ mouse induced rapid augmentation of the TNF level in BALF (Fig. 2a) and the TNF levels were dose-dependent when assayed $2 \mathrm{~h}$ after inoculation (Fig. 2b). As LPS did not increase neutrophils within $2 \mathrm{~h}$ of inoculation (Figs. 1a and 2a), these findings indicate that TNF in BALF comes mainly from AMs rather than neutrophils. However, no TNF was detected in the sera (Fig. 2b). In contrast, intratracheal administration of $2^{-1}$ LD50 of ETA, AP and EL did not produce any detectable TNF in BALF (Fig. 2a) and sera (data not shown) until $48 \mathrm{~h}$ after inoculation.
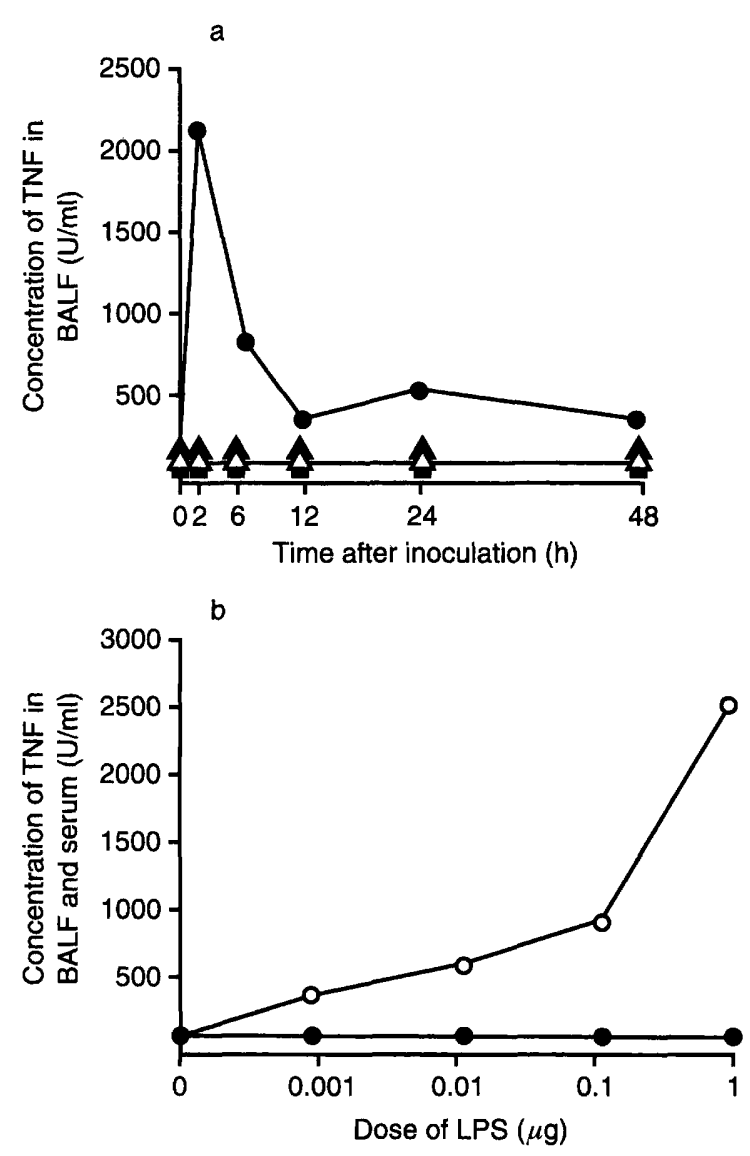

Fig. 2. TNF levels in BALF and sera of mice after intratracheal inoculation of LPS $(\bullet)$, AP $7.5 \mu \mathrm{g}(\boldsymbol{\Delta})$, EL $1.2 \mu \mathrm{g}(\triangle)$ or ETA $0.1 \mu \mathrm{g}(\boldsymbol{\square})$. Mice were inoculated intratracheally with $1 \mu \mathrm{g}$ of LPS or $2^{-1}$ LD50 of $P$. aeruginosa AP, EL or ETA and kinetics of TNF levels in BALF were assessed by L929 cytotoxic assay (a). TNF levels in BALF (O) and in serum (•) $2 \mathrm{~h}$ after intratracheal inoculation of various doses of LPS were also examined (b). The results are expressed as the mean of at least three mice per group.
Influence of pre-inoculation with ETA, AP or EL on LPS-induced TNF production in BALF

Although ETA, AP and EL themselves lack the ability to induce intratracheal TNF production, these substances may influence LPS-induced TNF production in BALF. Pre-inoculation with AP and EL did not show any obvious effect on LPS-induced TNF production in BALF (data not shown). In contrast, previous inoculation with ETA $(0.05$ or $0.1 \mu \mathrm{g} /$ mouse $)$ suppressed LPS-induced TNF production in a dose-dependent manner, and complete suppression was obtained by pre-treatment with $0.1 \mu \mathrm{g}$ of ETA following stimulation with $0.01 \mu \mathrm{g}$ of LPS (p<0.01, Fig. 3).

\section{Suppressive effect of ETA on TNF- $\alpha$ mRNA expression in $B A L F$}

As shown in Fig. 4, the expression of TNF- $\alpha$ mRNA (354 bp) in BALF obtained after pretreatment with

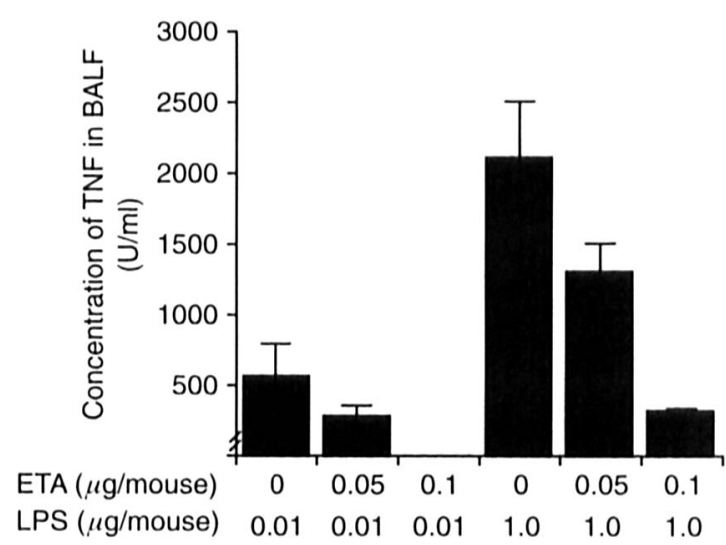

Fig. 3. Suppressive effect of previous inoculation of ETA on LPS-induced TNF production in BALF. Various doses of ETA were inoculated intratracheally $4 \mathrm{~h}$ in advance and then LPS $(0.01$ or $1.0 \mu \mathrm{g})$ was inoculated via the same route. BALF was obtained $2 \mathrm{~h}$ after LPS challenge and TNF levels in BALF were assessed. The results are expressed as the mean and SD in triplicate wells.

\section{ETA}

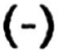

(+)

TNF $\alpha(354$ bp)

$\beta-\operatorname{actin}(245 \mathrm{bp})$

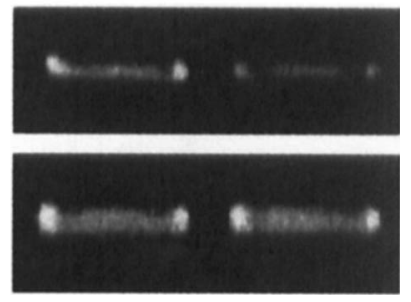

Fig. 4. Effect of previous treatment of ETA on LPSinduced TNF- $\alpha$ mRNA expression in BALF cells. Mice that had been inoculated intratracheally with ETA $(0.1 \mu \mathrm{g} /$ mouse $) 4 \mathrm{~h}$ earlier were inoculated with LPS $(0.01 \mu \mathrm{g})$ via the same route and $90 \mathrm{~min}$ later BALF was collected. TNF- $\alpha$ mRNA expression in the BALF cells was assessed by RT-PCR. 
ETA and LPS stimulation was less than that obtained after inoculation of LPS only. No difference was seen in the expression of $\beta$-actin mRNA ( $245 \mathrm{bp}$ ) in either group. This was also confirmed by a spectrophotometric estimation (data not shown). The ratio of TNF- $\alpha$ mRNA $/ \beta$-actin mRNA was 0.81 in the group inoculated with LPS and 0.42 in the group pre-treated with ETA and inoculated with LPS. Cell viability was not influenced by ETA, which was estimated by MTT reduction test as described above (data not shown).

\section{Suppressive effects of ETA on in-vitro LPS- induced TNF production by macrophages}

To examine whether ETA directly affected TNF production by TNF producer cells, AMs were cultured in the presence or absence of various concentrations of ETA, and then stimulated with LPS $1 \mu \mathrm{g} / \mathrm{ml}$. As shown in Fig. 5, the greater the dose of ETA added to macrophage cultures, the lower the production of TNF.

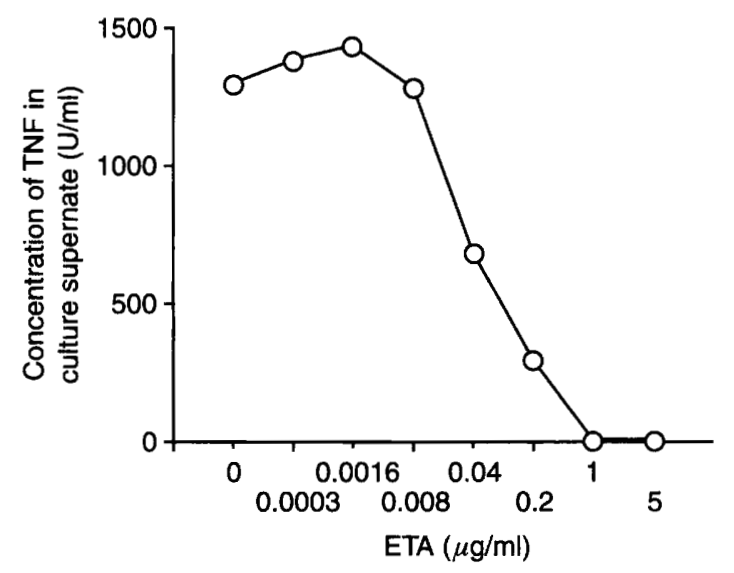

Fig. 5. Effect of previous treatment with ETA on LPSinduced TNF production by AMs in vitro. AMs obtained from BALF were cultured in the presence or absence of ETA $(0.008-5 \mu \mathrm{g} / \mathrm{ml})$ for $4 \mathrm{~h}$ and then stimulated with LPS (final concentration $1000 \mathrm{ng} / \mathrm{ml}$ ) for $2 \mathrm{~h}$. At the end of cultivation, culture supernates were collected and TNF levels in the supernates were assessed.

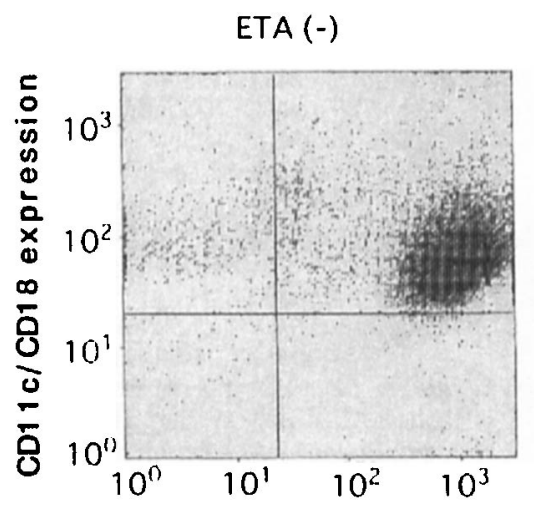

ETA itself at the concentration used did not affect cell viability as determined by the MTT reduction test over $12 \mathrm{~h}$ (data not shown).

\section{Down-regulation of CD14- and CD11c/CD18- positive cells by ETA}

The expression of CD14 and CD11c/CD18 on the cells in BALF, which are presumed to be receptors for LPS and participate in LPS-induced cytokine production $[25,26]$, was analysed by two-colour flow cytometry. As shown in Fig. 6, the cells in BALF obtained from normal mice were $98.1 \%$ CD14 positive and $94.7 \%$ CD11c/CD18 positive, including $93.3 \%$ double positive cells. On the other hand, macrophages in BALF obtained from the mice pre-treated with ETA were $41.0 \%$ CD14 positive and $49.3 \%$ CD11c/CD18 positive, including $36.3 \%$ double positive cells. These findings indicate that pre-treatment with ETA reduces the cells bearing CD14 and CD11c/CD18 molecules in BALF. ETA did not influence cell viability as determined by the MTT reduction test (data not shown).

\section{Discussion}

High concentrations of TNF and other cytokines such as interleukin- $1 \beta$ (IL-1 $\beta$ ), IL-6, IL- 8 and other molecules including intracellular adhesion molecule-1 (ICAM-1) and IL-1 receptor antagonist (IL-1Ra) have been detected in the sputum or BALF from CF patients [6-8]. High levels of IL- $1 \beta$, IL-1Ra, IL- 8 and TNF are also found in BALF from patients with DPB $[9,27]$. This suggests that cytokines and other molecules play important roles in the pathogenesis of respiratory infections caused by $P$ aeruginosa in CF and DPB. The significance of endotoxin in the pathogenesis of $P$. aeruginosa infections has been reported extensively, while the role of exo-enzymes and the interactions of LPS and exo-enzymes are less well understood despite the strong expression of these molecules in sputum and

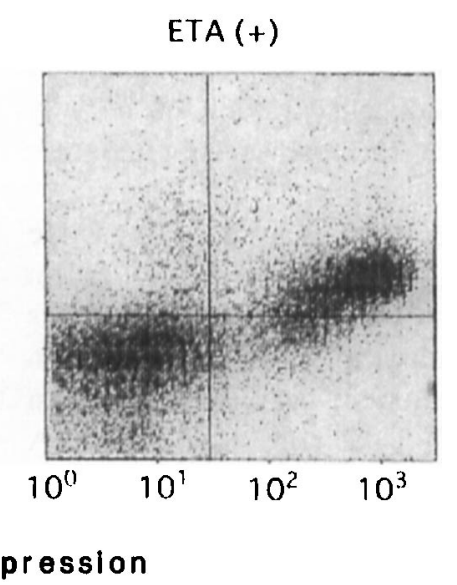

Fig. 6. Influence of ETA on CD14 and CD11c/CD18 expression on the surface of murine AMs. Total cells in BALF obtained from control mice, ETA $(-)$, and mice inoculated with ETA $4 \mathrm{~h}$ before, ETA $(+)$, were adjusted to $1.0 \times 10^{6} \mathrm{cells} / \mathrm{ml}$ and stained with FITC-conjugated anti-CD14 MAb and PE-conjugated anti-CD $11 \mathrm{c} / \mathrm{CD} 18 \mathrm{MAb}$. Labelled cells were gated in an area of macrophages on the scatter cytogram and analysed by Cytron flow cytometry. 
BALF of CF patients [13, 14]. Recently, it has been reported that low-dose and long-term treatment with erythromycin or other macrolides improves the clinical symptoms and prognosis of patients with DPB $[9,27-$ 29]. An earlier study reported that macrolides suppress the production of $P$. aeruginosa exo-enzymes in vitro $[28,30]$. This is one possible role for macrolides in $P$. aeruginosa infections.

Earlier work also reported that ETA was detected in the serum of mice with endogenous $P$. aeruginosa septicaemia, and that systemic administration of ETA before or at the same time as LPS injection enhanced LPS-induced TNF production in murine serum [12]. The findings suggest that ETA is responsible for enhancing the production to a lethal dose of TNF in the presence of LPS in systemic $P$. aeruginosa infection.

It is of interest that in the present study, ETA suppressed LPS-induced TNF production in murine lung; the opposite was the case in the systemic model. The strongest priming effect of ETA in LPS-induced TNF production in the systemic model was observed when ETA was administered $4 \mathrm{~h}$ before LPS. In the lung model reported here, ETA was also injected $4 \mathrm{~h}$ before LPS inoculation. These findings also showed that administration of ETA did not change total cell number or the percentage of neutrophils, suggesting that participation of neutrophils in the suppressive effect of ETA can be neglected in this experimental schedule. A difference of local concentration of ETA between systemic and lung models may be one reason for the discrepancy. However, a wide range of ETA concentrations suppressed TNF production by AMs in vitro, indicating that other mechanisms are involved. TNF is capable of increasing host resistance to bacterial infection [31]. The suppressive effect of ETA on LPS-induced TNF production may weaken the role of TNF in the augmentation of host resistance and favour the infecting $P$. aeruginosa organisms. Jaffar-Bandjee et al. [13] reported increased levels of exo-enzymes in sputum of CF patients (levels of ETA, $\mathrm{EL}$ and $\mathrm{AP}$ were $0.3-126,0.3-79$ and $0.3-32 \mathrm{ng} / \mathrm{ml}$, respectively). The dose and concentration of ETA in the present study is similar to those in their report.

ETA is a protein toxin that inhibits polypeptide synthesis through ADP ribosylation of elongation factor 2, as does diphtheria toxin [32]. Recent studies have reported the immunological activities of ETA in addition to its direct cytotoxicity against mammalian cells. Holt and Misfeldt [33] demonstrated that ETA modulates the in-vitro and in-vivo antibody response in mice. ETA has also been reported to stimulate invitro production of IL-1 in murine peritoneal macrophages [34] and to induce murine cytotoxic $T$ lymphocytes [35]. Staugas et al. [36] reported that ETA depresses lymphoproliferation, TNF, lymphotoxin, $\gamma$-interferon and IL-1 production in human leucocytes in vitro. Although the influence of ETA on cytokine production varied in these studies, it is possible that ETA acts as an immunomodulator through regulatory cytokines or other factors.

The findings of the present study suggest that ETA suppressed the expression of CD14 and CD11c/CD18 molecules (presumed LPS receptor molecules) on the membrane surfaces of AMs, the expression of TNF mRNA in AMs and protein synthesis and/or secretion of TNF. The suppression of the expression of TNF mRNA may be secondary to the depressed expression of the LPS receptors CD14 [25] and CD11c/CD18 [26] on the surface of AMs. As production of TNF was completely inhibited in spite of only a partial depression of mRNA, protein synthesis or secretion of TNF, or both, is probably involved. The clinical significance of the TNF-suppressing effect of ETA in the lung is still unclear. It is speculated that ETA regulates the severe acute inflammation caused by LPS and induces chronic inflammation.

We are grateful to Kazuto Tsuruda for technical expertise in flow cytometry.

\section{References}

1. Neu HC. The role of Pseudomonas aeruginosa in infections. $J$ Antimicrob Chemother 1983; 11 Suppl B: 1-13.

2. Wood RE, Boat TF, Doershuk CF. Cystic fibrosis. Am Rev Respir Dis 1976; 113: 833-878.

3. Mahenthiralingam E, Speert DP. Nonopsonic phagocytosis of Pseudomonas aeruginosa by macrophages and polymorphonuclear leukocytes requires the presence of the bacterial flagellum. Infect Immun 1995; 63: 4519-4523.

4. Homma H, Yamanaka A, Tanimoto $\mathrm{S}$ et al. Diffuse panbronchiolitis: a disease of the transitional zone of the lung. Chest 1983; 83: 63-69.

5. Fujii $\mathrm{T}$, Kadota J, Kawakami $\mathrm{K}$ et al. Long term effect of erythromycin therapy in patients with Pseudomonas aeruginosa infection. Thorax 1995; 50: 1246-1252.

6. Kronborg G, Hansen MB, Svenson M, Fomsgaard A, Hoiby N, Bendtzen $\mathrm{K}$. Cytokines in sputum and serum from patients with cystic fibrosis and chronic Pseudomonas aeruginosa infection as markers of destructive inflammation in the lungs. Pediatr Pulmonal 1993; 15: 292-297.

7. Bonfield TL, Panuska JR, Konstan MW et al. Inflammatory cytokines in cystic fibrosis lungs. Am J Respir Crit Care Med 1995; 152: 2111-2118.

8. Salva PS, Doyle NA, Graham L, Eigen H, Doerschuk CM. TNF-alpha, IL-8, soluble ICAM-1, and neutrophils in sputum of cystic fibrosis patients. Pediatr Pulmonal 1996; 21: 11-19.

9. Sakito O, Kadota J, Kohno S, Abe K, Shirai R, Hara K. Interleukin 1 beta, tumor necrosis factor alpha, and interleukin 8 in bronchoalveolar lavage fluid of patients with diffuse panbronchiolitis: a potential mechanism of macrolide therapy. Respiration 1996; 63: 42-48.

10. Liu PV. Extracellular toxins of Pseudomonas aeruginosa. J Infect Dis 1974; 130 Suppl: S94-S99.

11. Nicas TI, Iglewski BH. The contribution of exoproducts to virulence of Pseudomonas aeruginosa. Can J Microbiol 1985; 31: $387-392$.

12. Hirakata Y, Furuya N, Tateda K, Kaku M, Yamaguchi K. In vivo production of exotoxin $\mathrm{A}$ and its role in endogenous Pseudomonas aeruginosa septicemia in mice. Infect Immun 1993; 61: 2468-2473.

13. Jaffar-Bandjee MC, Lazdunski A. Bally $M$, Carrère J, Chazalette JP, Galabert C. Production of elastase, exotoxin A, and alkaline protease in sputa during pulmonary exacerbation of cystic fibrosis in patients chronically infected by Pseudo- 
monas aeruginosa J Clin Microbiol 1995; 33: 924-929.

14. Suter $\mathrm{S}$. The role of bacterial proteases in the apathogenesis of cystic fibrosis. Am J Respir Crit Care Med 1994; 150: S118-122.

15. Brauner A, Cryz SJ, Granstrom $M$ et al. Immunoglobulin $\mathrm{G}$ antibodies to Pseudomonas aeruginosa lipopolysaccharides and exotoxin A in patients with cystic fibrosis or bacteremia. Eur $J$ Clin Microbiiol Infect Dis 1993; 12: 430-436.

16. Doring G, Obernesser H-J, Botzenhart K, Flehmig B, Høily N, Hofmann A. Proteases of Pseudomonas aeruginosa in patients with cystic fibrosis. $J$ Infect Dis 1983; 147: 744-750.

17 Woods DE, Cryz SJ, Friedman RL, Iglewski BH. Contribution of toxin A and elastase to virulence of Pseudomonas aeruginosa in chronic lung infections of rats. Infect Immun 1982; 36: $1223-1228$.

18. Karber G. Beitrag zur kollektiven Behandlung pharmakologischer Reihenversuche. Arch Exp Pathol Pharmocol 1931; 162: 480 .

19. Irifune K, Shimoguchi K, Tateda K, Yamaguchi K, Hara K. A simple method of intratracheal inoculation into mice. $J$ Clin Exp Med 1990; 152: 71 .

20. Kirikae F, Kirikae T, Qureshi N, Takayama K, Morrison DC, Nakano M. CD14 is not involved in Rhodobacter sphaeroides dishosphoryl lipid A inhibition of tumor necrosis factor alpha and nitric oxide induction by taxol in murine macrophages. Infect Immun 1995; 63: 486-497.

21. Ito $T$, Kito $K$, Adati N, Mitsui Y, Hagiwara H, Sasaki Y. Fluorescent differential display: arbitrarily primed RT-PCR fingerprinting on an automated DNA sequencer. FEBS Lett 1994; 351: $231-236$.

22. Kawasaki ES, Clark SS, Coyne MY et al. Diagnosis of chronic myeloid and acute lymphocytic leukemias by detection of leukemia-specific mRNA sequences amplified in vitro. Proc Natl Acad Sci USA 1988; 85: 5698-5702.

23. Pennica D, Hayflick JS, Bringman TS, Palladino MA, Goeddel DV. Cloning and expression in Escherichia coli of the cDNA for murine tumor necrosis factor. Proc Natl Acad Sci USA 1985; 82: 6060-6064.

24. Fujihara M, Ito N, Pace JL, Watanabe Y, Russell SW, Suzuki $T$. Role of endogenous interferon- $\beta$ in lipopolysaccharidetriggered activation of the inducible nitric-oxide synthase gene in a mouse macrophage cell line, J774. J Biol Chem 1994; 269: $12773-12778$.

25. Golenbock DT, Liu Y, Millham FH, Freeman MW, Zoeller RA.
Surface expression of human CD14 in Chinese hamster ovary fibroblasts imparts macrophage-like responsiveness to bacterial endotoxin. J Biol Chem 1993; 268: 22055-22059.

26. Ingalls RR, Golenbock DT. CD11c/CD18, a transmembrane signaling receptor for lipopolysaccharide. J Exp Med 1995; 181: $1473-1479$.

27. Kadota J, Matsubara Y, Ishimatsu Y et al. Significance of IL-1 beta and IL-1 receptor antagonist (IL-1Ra) in bronchoalveolar lavage fluid (BALF) in patients with diffuse panbronchiolitis (DPB). Clin Exp Immunol 1996; 103: 461-466.

28. Hirakata Y, Kaku M, Mizukane $\mathrm{R}$ et al. Potential effects of erythromycin on host defense systems and virulence of Pseudomonas aeruginosa. Antimicrob Agents Chemother 1992; 36: 1922-1927.

29. Yanagihara K, Tomono K, Sawai $\mathrm{T}$ et al. Effect of clarithromycin on lymphocytes in chronic respiratory Pseudomonas aeruginosa infection. Am J Respir Crit Care Med 1997; 155: 337-342.

30. Mizukane R, Hirakata Y, Kaku M et al. Comparative in vitro exoenzyme-suppressing activities of azythromycin and other macrolide antibiotics against Pseudomonas aeruginosa. Antimicrob Agents Chemother 1994; 38: 528-533.

31. Nakano Y, Onozuka K, Terada Y, Shinomiya H, Nakano M. Protective effect of recombinant tumor necrosis factor- $\alpha$ in murine salmonellosis. J Immunol 1990; 144: 1935-1941.

32. Iglewski BH, Sadoff JC. Toxin inhibitors of protein synthesis: production, purification, and assay of Pseudomonas aeruginosa toxin A. Methods Enzymol 1979; 60: 780-793.

33. Holt PS, Misfeldt ML. Alteration of murine immune response by Pseudomonsa aeruginosa exotoxin A. Infect Immun 1984; 45: $227-233$.

34. Misfeldt ML, Legaard PK, Howell SE, Fornella MH, LeGrand $\mathrm{RD}$. Induction of interleukin-1 from murine peritoneal macrophages by Pseudomonas aeruginosa exotoxin A. Infect Immun 1990; 58: 978-982.

35. Zehavi-Willner T. Induction of murine cytotoxic $\mathrm{T}$ lymphocytes by Pseudomonas aeruginosa exotoxin A. Infect Immun 1988; 56: $213-218$.

36. Staugas REM, Harvey DP, Ferrante A, Nandoskar M, Allison AC. Induction of tumor necrosis factor (TNF) and interleukin-1 (IL-1) by Pseudomonas aeruginosa and exotoxin A-induced suppression of lymphoproliferation and TNF, lymphotoxin, gamma interferon, and IL-1 production in human leukocytes. Infect Immun 1992; 60: 3162-3168. 